\title{
Efektivitas Model Pembelajaran Tuntas dalam E-Modul Berbasis Project Based Learning
}

\author{
Luh Putu Diah Utami Chandra Sari ${ }^{1}$, Ketut Agustini ${ }^{2}$ \\ , I Made Ardwi Pradnyana 3 \\ Jurusan Pendidikan Teknik Informatika \\ Fakultas Teknik dan Kejuruan \\ Universitas Pendidikan Ganesha \\ Singaraja, Bali \\ e-mail: dungchaa@gmail.com ${ }^{1}$, ketutagustini@undiksha.ac.id ${ }^{2}$, \\ ardwi.pradnyana@undiksha.ac.id ${ }^{3}$
}

\begin{abstract}
Abstrak
Salah satu media yang memenuhi kriteria sebagai media pembelajaran mandiri adalah modul elektronik (e-modul). E-modul merupakan sebuah media pembelajaran untuk menyampaikan materi kepada siswa. Tujuan dari penelitian ini adalah untuk mengimplementasikan dan merealisasikan pengembangan e-modul serta mengetahui respon guru dan siswa mengenai e-modul. Metode yang digunakan dalam penelitian ini adalah penelitian dan pengembangan (Research and Development) dengan model pengembangan ADDIE dan menggunakan platform schoology. Untuk mengetahui respon guru dan siswa terhadap e-modul Jaringan Dasar diperoleh dengan menggunakan metode angket. Hasil penelitian menunjukkan bahwa: Hasil rancangan dan realisasi Pengembangan E-Modul Berbasis Model Pembelajaran Projet Based Learning pada Mata Pelajaran Jaringan Dasar dinyatakan berhasil diterapkan berdasarkan beberapa uji yang dilakukan. Hasil analisis data respon guru menunjukkan bahwa didapatkan rata-rata skor sebesar 46, jika dikonversikan ke dalam tabel penggolongan respon maka termasuk pada kategori positif. Sedangkan untuk respon siswa terhadap pengembangan e-modul didapatkan rata-rata skor respon sebesar 64,21, jika dikonversikan ke dalam tabel penggolongan respon siswa termasuk pada kategori positif.
\end{abstract}

Kata kunci: E-Modul, Model Pembelajaran Project Based Learning, Platform Schoology, Model ADDIE

\begin{abstract}
One of the media that meets the criteria as an independent learning media is the electronic module (e-modules). E-module is a learning media for delivering material to students. The purpose of this study is to implement and realize the development of emodules as well as knowing the responses of teachers and students regarding-modules. The method used in this study is Research and Development with the ADDIE model development and using schoology platform. To determine the response of teachers and student to basic network e-module obtained using the questionnaire method. The result of the study showed: design and realization of development of e-modules based on the project based learning model on Basic Network declared successful based on several tests performed. The results of the teacher response data analysis showed that the average score was 46, if converted into the response classification table it belongs to the positive category. While for students' responses to the development of e-modules, the average response score was 64.21 , if converted into the student response classification table included in the positive category.
\end{abstract}

Keywords : E-Modules, Project Based Learning Model, Schoology Platform, ADDIE Model 


\begin{abstract}
Belajar adalah proses seseorang memperoleh berbagai kecakapan, keterampilan, dan sikap (Aunurrahman, 2009). Salah satu pertanda bahwa individu telah belajar adalah adanya perubahan tingkah laku dari individu yang bersangkutan yang disebabkan oleh terjadinya perubahan pada tingkat pengetahuan, sikap, dan keterampilan. Seiring dengan perubahan kurikulum pada tahun 2013 yang mengubah Kurikulum Tingkat Satuan Pendidikan (KTSP) menjadi Kurikulum 2013 membawa perubahan besar pada dunia pendidikan. Berdasarkan Peraturan Pemerintah No. 17 (2010) menyatakan bahwa: "Dalam menyelenggarakan dan mengelola pendidikan, satuan dan/atau program pendidikan mengembangkan dan melaksanakan sistem informasi pendidikan berbasis teknologi informasi dan komunikasi".
\end{abstract}

SMK TI Bali Global Singaraja merupakan salah satu SMK di Buleleng yang menggunakan kurikulum 2013. SMK TI Bali Global Singaraja memiliki tiga (3) kompetensi keahlian, salah satunya adalah kompetensi keahlian Teknik Komputer dan Jaringan (TKJ). Dalam kompetensi keahlian TKJ terdapat mata pelajaran khusus atau yang biasa disebut dengan mata pelajaran produktif. Setelah dilakukan observasi, wawancara, dan penyebaran angket di kelas $X$ TKJ pada mata pelajaran jaringan dasar, diperoleh informasi bahwa media pembelajaran yang digunakan belum sesuai dengan tuntutan kemajuan arus informasi yang memanfaatkan teknologi informasi dan komunikasi sebagai sistem informasi pendidikan. Media yang digunakan saat proses pembelajaran berupa presentasi menggunakan power point yakni materi yang tersampaikan hanya inti dari materi yang diajarkan. Dalam proses pembelajaran guru menggunakan model pembelajaran konvensional/ceramah dimana sistem pembelajaran konvensional kurang fleksibel dalam mengakomodasi perkembangan materi kompetensi karena

\section{PENDAHULUAN}

pendidik harus intensif menyesuaikan materi pelajaran dengan perkembangan teknologi baru (Agustini, 2013). Dari permasalahan tersebut, siswa kelas X TKJ menuturkan bahwa mereka memerlukan media pembelajaran dengan materi yang dipaparkan secara tidak membosankan, dalam artian tidak hanya berupa teks namun juga terdapat gambar danvideo animasi yang menggambarkan konsepkonsep dari materi-materi yang masih abstrak menjadi lebih konkret sehingga menghasilakan media pembelajaran yang valid, praktis, dan efektif yang dapat meningkatkan mutu serta kualitas pembelajaran.

Salah satu media yang memenuhi kriteria sebagai media pembelajaran mandiri adalah modul elektronik (e-modul). E-modul merupakan sebuah media pembelajaran untuk menyampaikan materi kepada siswa. E-modul dapat didefinisikan sebagai sebuah bentuk penyajian bahan belajar mandiri yang disusun secara sistematis ke dalam unit pembelajaran terkecil untuk mencapai tujuan pembelajaran tertentu, yang disjaikan dalam format elektronik yang setiap kegiatan pembelajaran di dalamnya dihubungkan dengan link-link sebagai navigasi yang membuat peserta didik menjadi interaktif dengan program, dilengkapi dengan penyajian video tutorial, animasi dan audio untuk memperkaya pengalaman belajar (Gunadharma, 2011).

Dalam proses pembelajaran jaringan dasar kelas X TKJ SMK TI Bali Global Singaraja menggunakan model pembelajaran berbasis proyek (project based learning). Model pembelajaran berbasis proyek sendiri didefinisikan sebagai model pembelajaran yang melibatkan suatu proyek/kegiatan sebagai media dalam proses pembelajaran. Pada penelitian ini e-modul yang dikemas dengan model pembelajaran project based learning (PjBL) akan disusun dengan bantuan platform inovatif yaitu Schoology. 
Schoology adalah situs yang menggabungkan antara Social Learning Networks (SLNs) dan Learning Management System (LMS) untuk K-12 sekolah, lembaga pendidikan tinggi, dan berbagai konten sumber daya. Schoology berbentuk web sosial yang menawarkan pembelajaran sama seperti di dalam kelas secara percuma (gratis) dan mudah digunakan seperti media sosial Facebook (Putri, 2014). Selain itu Schoology juga didukung oleh berbagai bentuk media seperti video, audio, dan gambar yang dapat menarik minat siswa. Schoology membantu siswa membuat laporan,

\section{METODOLOGI PENELITIAN}

A. Model Pengembangan

Model penelitian merupakan dasar untuk mengembangkan produk yang akan dihasilkan. Penelitian ini menggunakan desain pengembangan model ADDIE. Model ini dipilih karena merupakan salah satu model perencanaan pembelajaran yang efektif dan efisien serta prosesnya bersifat interaktif, dimana hasil evaluasi setiap fase dapat membawa mencari informasi tentang kelas, dan lain sebagainya. Schoology mengarahkan siswa mengaplikasikan penggunaan teknologi dalam pembelajaran.

Berdasarkan uraian di atas, adanya pengembangan e-modul dalam proses pembelajaran sangat penting karena dapat menambah bahan belajar siswa. Terkait hal ini, peneliti melakukan pengembangan emodul dalam penelitian dengan judul "Pengembangan E-Modul Berbasis Model Pembelajaran Project Based Learning pada Mata Pelajaran Jaringan Dasar Kelas $X$ Teknik Komputer dan Jaringan di SMK TI Bali Global Singaraja.

pengembangan pembelajaran ke fase sebelumnya. Model ADDIE terdiri dari lima tahapan pengerjaan, yaitu Analyze (Analisis), Design (Perancangan), Development (Pengembangan), Implementation (Implementasi), dan Evaluation (Evaluasi). Siklus model ADDIE dapat dilihat pada Gambar 2.

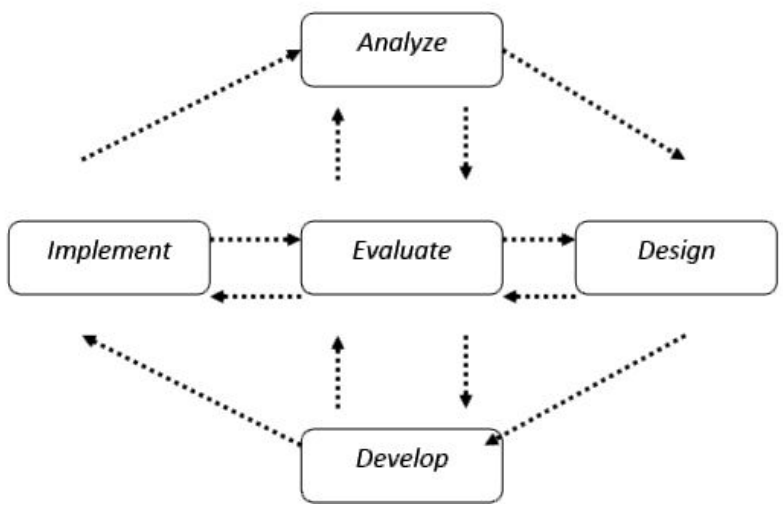

Gambar 2. Tahapan Model ADDIE (Anglada, 2007)

B. Teknik Pengumpulan Data

Data yang dikumpulkan untuk dianalisis bersifat kualitatif dan kuantitatif dalam penelitian ini, yaitu meliputi informasi sumber belajar, kevalidan, kepraktisan, dan keefekifan e-modul, serta respon guru dan siswa terhadap e-modul yang dikembangkan. Teknik pengumpulan data dapat dilihat pada Tabel 1 .

Tabel 1. Teknik Pengumpulan Data

\begin{tabular}{|c|l|c|c|}
\hline No & Jenis Data & Metode & \multicolumn{2}{|c|}{$\begin{array}{c}\text { Sumber } \\
\text { Data }\end{array}$} \\
\hline 1 & Informasi & Angket & Guru Mata \\
\hline
\end{tabular}




\begin{tabular}{|c|l|c|l|}
\hline No & Jenis Data & Metode & \multicolumn{1}{|c|}{$\begin{array}{c}\text { Sumber } \\
\text { Data }\end{array}$} \\
\hline $\begin{array}{l}\text { tentang } \\
\text { sumber } \\
\text { belajar }\end{array}$ & $\begin{array}{c}\text { dan } \\
\text { wawanc } \\
\text { ara }\end{array}$ & Pelajaran \\
\hline 2 & $\begin{array}{l}\text { Karakteristik } \\
\text { pembelajara } \\
\mathrm{n}\end{array}$ & Angket & $\begin{array}{l}\text { Siswa kelas X } \\
\text { TKJ SMK TI } \\
\text { Bali Global } \\
\text { Singaraja }\end{array}$ \\
\hline 3 & $\begin{array}{l}\text { Kevalidan e- } \\
\text { modul }\end{array}$ & Angket & $\begin{array}{l}\text { Ahli Isi, Ahli } \\
\text { Desain, dan } \\
\text { Ahli Media }\end{array}$ \\
\hline 4 & $\begin{array}{l}\text { Keefektivan } \\
\text { e-modul }\end{array}$ & Angket & $\begin{array}{l}\text { Uji } \\
\text { perorangan, } \\
\text { Uji kelompok } \\
\text { kecil, dan Uji } \\
\text { lapangan }\end{array}$ \\
\hline 5 & $\begin{array}{l}\text { Respon e- } \\
\text { modul }\end{array}$ & Angket & $\begin{array}{l}\text { Guru mata } \\
\text { pelajaran } \\
\text { Jaringan dasar } \\
\text { dan Siswa } \\
\text { Kelas X SMK } \\
\text { TI Bali Global } \\
\text { Singaraja }\end{array}$ \\
\hline
\end{tabular}

Pada kegiatan observasi guna mendapat informasi sumber belajar dan karakteristik pembelajaran, digunakan jenis metode wawancara serta angket. Melalui metode wawancara dan angket ini diketahui masalah yang terjadi pada proses pembelajaran terkait sumber belajar, materi, media, dan ketertarikan serta karakteristik siswa dalam pembelajaran Jaringan Dasar.

Metode angke digunakan untuk mengumpulkan data pada saat menganalisis pembelajran dan proses uji coba ahli isi bidang studi atau mata pelajaran, ahli media pembelajaran, ahli desain media pembelajaran, uji perorangan, kelompok dan uji lapangan

Angket guru dan siswa terdiri dari lima pilihan yaitu Sangat Setuju (SS), Setuju (S). Kurang Setuju (KS), Tidak Setuju (TS), dan Sangat Tidak Setuju (STS). Sedangkan angket untuk ahli isi, ahli desain, dan ahli media pembelajaran terdiri dari dua pilihan, yaitu Sesuai (S) dan Tidak Sesuai (TS). Untuk skor pada angket uji coba dapat dilihat pada Tabel 2.

Tabel 2. Skor Pernyataan

\begin{tabular}{|l|c|c|}
\hline Alternatif & Skor Positif & Skor Negatif \\
\hline $\begin{array}{l}\text { Sangat } \\
\text { Setuju (SS) }\end{array}$ & 5 & 1 \\
\hline Setuju (S) & 4 & 2 \\
\hline $\begin{array}{l}\text { Kurang } \\
\text { Setuju (KS) }\end{array}$ & 3 & 3 \\
\hline $\begin{array}{l}\text { Tidak Setuju } \\
\text { (TS) }\end{array}$ & 2 & 4 \\
\hline $\begin{array}{l}\text { Sangat Tidak } \\
\text { Setuju (STS) }\end{array}$ & 1 & 5 \\
\hline
\end{tabular}

C. Teknik Analisis Data

Analisis data pada penelitian pengembangan ini bertujuan untuk menjawab rumusan masalah dalam kesimpulan. Berikut ini merupakan teknik analisis data yang digunakan dalam penelitian ini.

1. Analisis Data Kevalidan E-Modul

Analisis data kevalidan e-modul dimaksudkan untuk mengetahui sejauh 
mana e-modul yang telah dibuat memenuhi kriteria berdasarkan penilaian validator yang ditunjuk dengan menggunakan lembar validasi ahli, hasil validasi ahli menajdi dasar dan pertimbangan dalam melakukan revisi.

2. Analisis Data Respon Guru dan Siswa

Analisis data respon siswa dan guru dimaksud untuk mengetahui bagaimana respon guru dan siswa terhadap e-modul yang dikembangkan.

D. Analisis Data Kevalidan E-Modul

Validasi e-modul diuji oleh ahli isi, ahli desain, ahli media, uji perorangan dan uji kelompok kecil, menganalisis respon guru dan siswa terhadap pengembangan emodul diuraikan sebagai berikut.

1) Uji Ahli Isi

Validasi ini bertujuan untuk mengetahui isi yang terkandung di dalam e-modul apakah sudah sesuai dengan konsep pengetahuan atau indikatir yang ingin dicapai. Peneliti melibatkan guru yang mengajar mata pelajaran jaringan dasar sebagai ahli karena mengetahui secara detail kegiatan pembelajran yang dilakukan.

Penilaian hasil dari uji ahli isi dihitung dengan rumus Gregory yang mana menurut (Candiasa, 2010) mengembangkan teknik dalam pengujian isi yang sudah dikuantitatifkan. Mekanisme perhitungan pengujian validitas isi menurut Gregory adalah sebagai berikut.

a. Para pakar yang dipercaya menilai instrumen melakukan penilaian instrumen perbutir.

b. Pengelompokkan skala, sesuai dan tidak sesuai

c. Hasil penilaian para pakar ditabulasi silang, misalnya untuk dua penilai seperti pada Tabel 3 .

Tabel 3. Tabulasi Penilaian Akhir

\begin{tabular}{|c|c|c|c|}
\hline & \multicolumn{2}{|c|}{ PENILAI 1} \\
\hline & & $\begin{array}{l}\text { Tidak } \\
\text { Sesuai }\end{array}$ & Sesuai \\
\hline \multirow{2}{*}{$\begin{array}{l}\text { PENILAI } \\
2\end{array}$} & $\begin{array}{l}\text { Tidak } \\
\text { Sesuai }\end{array}$ & (A) & (B) \\
\hline & Sesuai & (C) & (D) \\
\hline
\end{tabular}

Perhitungan validitas isi dengan rumus:

$$
\text { Validitas Isi }=\frac{D}{A+B+C+D}
$$

Keterangan:

$\mathrm{A}=$ Sel yang menunjukkan ketidaksetujuan antara kedua penilai
$\mathrm{B}$ dan $\mathrm{C}=$ Sel yang menunjukkan perbedaan pandangan antara penilai

D = Sel yang menunjukkan persetujuan valid antara kedua penilai.

Untuk melihat tingkat pencapaian kriteria validitas Uji Ahli dapat dilihat pada Tabel 4.

Tabel 4. Kriteria Tingkat Validitas Isi

\begin{tabular}{|c|c|}
\hline Koefisien Validitas & Tingkat Validitas \\
\hline $0,91-1,00$ & Sangat Tinggi \\
\hline $0,71-0,90$ & Tinggi \\
\hline $0,41-0,79$ & Cukup \\
\hline $0,21-0,40$ & Rendah \\
\hline $0,00-0,20$ & Sangat Rendah \\
\hline
\end{tabular}

2) Uji Ahli Media dan Desain 
Validasi media dan desain dilakukan oleh ahli media dan desain pembelajaran. Untuk validasi media dan desain pembelajaran dilakukan dengan menggunakan angket dimana melibatkan orang yang ahli dalam bidang media dan desain pembelajaran. Penilaian pada uji ahli media dan desain dihitung dengan rumus Gregory (Gregory, 2000).

Keterangan:

$$
\Sigma=\text { jumlah }
$$

$\mathrm{n}=$ jumlah seluruh item angket

Selanjutnya, untuk menghitung persentase keseluruhan subjek digunakan rumus:

Keterangan:

$$
\text { persentase }=(\mathrm{F}: \mathrm{N})
$$

3) Uji Coba Perorangan

Validasi perorangan dilakukan oleh kelas yang mendapat mata pelajaran jaringan dasar. Validasi perorangan dilakukan dengan menggunakan angket. Rumus yang digunakan menghitung persentase masing-masing subyek menurut (Tegeh \& Kirna, 2010) sebagai berikut.

$\mathrm{F}=$ jumlah persentase keseluruhan subjek

$\mathrm{N}$ = banyak subjek

Untuk dapat memberikan makna dan pengambilan keputusan maka digunakan ketetapan terhadap hasil review dan uji coba produk seperti pada Tabel 5

Tabel 5. Kualifikasi Tingkat Pencapaian

\begin{tabular}{|l|l|l|}
\hline \multicolumn{1}{c|}{$\begin{array}{c}\text { Tingkat } \\
\text { Pencapaian (\%) }\end{array}$} & \multicolumn{1}{c|}{ Kualifikasi } & \multicolumn{1}{c|}{ Keterangan } \\
\hline $90 \leq \mathrm{P} \leq 100$ & Sangat baik & Tidak perlu direvisi \\
\hline $75 \leq \mathrm{P}<90$ & Baik & Sedikit direvisi \\
\hline $65 \leq \mathrm{P}<75$ & Cukup & Direvisi secukupnya \\
\hline $55 \leq \mathrm{P}<65$ & Kurang & Banyak hal yang direvisi \\
\hline $\mathrm{P}<55$ & Sangat kurang & Diulangi membuat produk \\
\hline
\end{tabular}

4) Uji Kelompok Kecil dan Lapangan Validasi kelompok kecil dan lapangan dilakukan dengan menggunakan angket. Rumus yang digunakan menghitung persentase kelompok kecil adalah rumus Tegeh \& Kirna (Tegeh \& Kirna, 2010).

5) Uji Normalitas Gain

Perhitungan ini menggunakan perhitungan $\mathrm{N}$-gain dimana Gain adalah peningkatan kemampuan yang dimiliki siswa setelah pembelajaran. Gain diperoleh dari selisih antara hasil pretest dan posttest. Data yang diperoleh dianalisis secara deskriptif, untuk menghitung peningkatan pemahaman atau penguasaan konsep siswa setelah pembelajaran berlangsung. Tujuannya adalah untuk menghindari hasil kesimpulan bias dalam penelitian. (Hake, 2002) mengembangkan sebuah alternatif untuk menjelaskan gain yang disebut gain yang ternormalisasi (normalized gain). Rata-rata $\mathrm{N}$-gain dihitung menggunakan rumus sebagai berikut

$$
N-\text { Gain }=\frac{\text { Skor Posttest }- \text { Skor Pretest }}{\text { Skor Maksimal }- \text { Skor Pretest }}
$$

Tabel 6. Kriteria Penggolongan N-Gain

\begin{tabular}{|c|c|}
\hline Indeks gain & Interpretasi \\
\hline$g>0,70$ & Tinggi \\
\hline $0,30<g<0,70$ & Sedang \\
\hline$g \leq 0,30$ & Rendah \\
\hline
\end{tabular}

6) Uji Respon Guru dan Siswa 
Tujuan akhir dalam pengembangan produk e-modul ini adalah untuk mengetahui respon guru dan siswa terhadap pengembangan e-modul dalam pembelajaran jaringan dasar. Untuk melakukan perhitungan analisis data respon guru dan siswa maka didasarkan pada rata-rata kelas $(\bar{x})$ dari respon guru dan siswa, Mi, SDi. Menurut (Nurkancana, \& Sunartana, 1992) ratarata kelas dari skor respon guru dan siswa dihitung menggunakan rumus:
Keterangan:

$X=$ rata-rata kelas untuk skor respon guru dan siswa

Sedangkan untuk mencari mean ideal (Mi) dan standar deviasi ideal (SDi)digunakan rumus sebagai berikut: $\mathrm{Mi}=\frac{1}{2}$ (skor maksimal ideal+skor terendah ideal) $\mathrm{SDi}=\frac{1}{6}$ (skor tertinggi ideal-skor terendah ideal)

$$
\mathrm{x}=\frac{\sum \mathrm{x}}{\mathrm{N}}
$$

$\sum x=$ jumlah skor respon guru dan siswa $N \quad$ = banyaknya guru dan siswa

Data respon siswa terhadap penerapan model pembelajaran Project based learning kemudian digolongkan kedalam kategori seperti pada Tabel 7 .

Tabel 7. Kriteria Penggolongan Respon Guru dan Siswa

\begin{tabular}{|l|l|l|}
\hline No. & \multicolumn{1}{|c|}{ Interval } & \multicolumn{1}{c|}{ Kategori } \\
\hline 1 & $\mathrm{Mi}+1,5 \mathrm{SDi} \leq \bar{x}$ & Sangat Positif \\
\hline 2 & $\mathrm{Mi}+0,5 \mathrm{SDi} \leq \bar{x}<\mathrm{Mi}+1,5 \mathrm{SDi}$ & Positif \\
\hline 3 & $\mathrm{Mi}-0,5 \mathrm{SDi} \leq \bar{x}<\mathrm{Mi}+0,5 \mathrm{SDi}$ & Kurang Positif \\
\hline 4 & $\mathrm{Mi}-1,5 \mathrm{SDi} \leq \bar{x}<\mathrm{Mi}-1,5 \mathrm{SDi}$ & Negatif \\
\hline 5 & $\bar{x}<\mathrm{Mi}-1,5 \mathrm{SDi}$ & Sangat Negatif \\
\hline
\end{tabular}

\section{HASIL DAN PEMBAHASAN}

Pengembangan e-modul mata pelajaran Jaringan Dasar memiliki tujuan untuk membantu penambahan sumber belajar, media pembelajaran, dan diharapkan dapat meningkatkan pemahaman terhadap materi pelajaran Jaringan Dasar selama proses belajar mengajar di kelas. . Berdasarkan hasil observasi awal yang dilakukan di SMK TI Bali Global Singaraja, diperoleh informasi bahwa media pembelajaran yang digunakan belum sesuai dengan tuntutan kemajuan arus informasi yang memanfaatkan teknologi informasi dan komunikasi sebagai sistem informasi pendidikan. Media yang digunakan saat proses pembelajaran berupa presentasi menggunakan power point yakni materi yang tersampaikan hanya inti dari materi yang diajarkan. Selain itu, siswa masih terpaku pada penjelasan dari guru yang menyebabkan siswa menjadi terbatas untuk melakukan pengembangan diri dengan potensi yang dimiliki dan mencari serta menemukan solusi secara mandiri. Salah satu upaya untuk dapat mencapai proses ini adalah dibutuhkan suatu media pembelajaran yang dikemasi dengan model pembelajaran sehingga dapat mengoptimalkan proses penyampaian materi. Salah satu media yang memenuhi kriteria sebagai media pembelajaran mandiri adalah e-modul (e-modul). E-modul merupakan sebuah media pembelajaran untuk menyampaikan materi kepada siswa.

E-modul Jaringan Dasar berperan sebagai bahan ajar serta media pembelajaran yang dapat membantu guru untuk mempermudah dalam penyampaian materi tanpa menggantikan peran guru sebagai pengajar. Pada penelitian ini $e-$ modul disusun dengan berbasis model pembelajaran project based learning. Model 
pembelajaran project based learning atau dikenal dengan model pembelajaran berbasis proyek sendiri didefinisikan sebagai model pembelajaran yang melibatkan suatu proyek/kegiatan sebagai media dalam proses pembelajaran. Proyek dikerjakan oleh siswa dapat berupa proyek perseorangan atau kelompok dan dilaksanakan dalam jangka waktu tertentu dan dipresentasikan.

Sesuai dengan tahapan pada desain penelitian yang digunakan yaitu model pengembangan ADDIE, tahapan pertama yang dilakuakn adalah analisis (analyze). Pada tahap ini dilakukan kegiatan analisis terhadap mata pelajaran, ketersediaan sumber belajar, dan analisis karakteristik siswa. Tahap kedua adalah perancangan (design). Pada tahap kedua ini peneliti telah merancang tujuan belajar yang menyesuaikan dengan kompetensikompetensi yang didapat dari tahap sebelumnya yaitu tahap analisis. Di tahap perancangan ini juga meliputi desain pengembangan e-modul, tahap perancangan peneliti menentukan Kompetensi Inti, Kompetensi Dasar, dan Indikator pembelajaran yang akan dikembangkan pada e-modul.

Tahap ketiga adalah pengembangan (development). Dimana pada tahap ini meliputi kegiatan pengembangan modul ajar dan pengembangan e-modul. Pada kegiatan penyusunan modul dilakukan pengumpulan sumber atau referensi untuk pengembangan materi pelajaran, kemudian pengetikan bahan ajar serta penyusunan materi sesuai kompetensi dan draft modul ajar. Setelah penyusunan modul selesai, dilanjutkan dengan perancangan sistem emodul, seperti membuat hak akses masuk ke halaman mata pelajaran, menyusun tampilan masing-masing pengguna (guru dan siswa), mengatur tampilan kegiatan pembelajaran, serta menerapkan materi ke sistem e-modul, dan mengintegrasikan fitur schoology pada e-modul. Pengembangan pada fitur schoology disesuaikan dengan kerangka modul yang digunakan dan berisikan implementasi tahapan project based learning.
Tahap keempat, implementasi (implementation), yang merupakan tindak lanjut dari tahap pengembangan. Tahap implementasi dilakukan dengan menguji coba e-modul sesuai dengan peran dan fungsinya dalam proses pembelajaran, untuk memperoleh gambaran tentang keefektifan, kemenarikan, dan kepraktisan e-modul pada pembelajaran. Dalam implementasinya, e-modul Jaringan Dasar menggunakan PC yang ada di lab jurusan TKJ. Guru akan menggunakan e-modul ini, kemudian siswa mengakses e-modul menggunakan PC yang tersedia di lab. Tahapan uji coba dimulai dari review para ahli, kemudian dilanjutkan dengan uji coba perorangan, kelompok kecil, dan uji lapangan. Uji ahli yang pertama dilakukan adalah uji ahli isi pembelajaran. Setelah melakukan uji ahli isi, kemudian dilanjutkan dengan uji ahli media dan desain pembelajaran.

Hasil penilaian ahli isi dengan menggunakan uji Gregory berdasarkan angket menunjukkan bahwa tingkat pencapaian dari e-modul adalah "Sangat Tinggi" dan layak untuk dilanjutkan. . Hal tersebut mengindikasikan bahwa materi pelajaran yang diimplementasikan dalam emodul sudah relevan untuk digunakan dalam pembelajaran Jaringan Dasar. Materi pelajaran yang memadukan sajian materi dari beberapa sumber buku sebagai referensi pembelajaran dinyatakan valid dan sudah sesuai dengan indikator dan tujuan pembelajaran pada silabus Jaringan Dasar.

Hasil penilaian uji ahli media dan desain pembelajaran berdasarkan angket menunjukkan bahwa tingkat pencapaiannya adalah "Sangat Tinggi", namun ada beberapa saran perbaikan dari penguji untuk melakukan perbaikan pada pengembangan e-modul Jaringan Dasar. Revisi tersebut di antaranya adalah ukuran font pada judul diperbesar dan di-bold, pada setiap gambar sertakan nama/judul gambar, dan detailkan kembali aturan 
pengerjaan proyek. Setelah itu dilakukan revisi oleh penulis untuk menyempurnakan pengembangan e-modul Jaringan Dasar.

Setelah melalui tahap para ahli, didapatkan hasil uji hali isi dengan hasil perhitungan 1,00 menunjukk pada kriteria "Sangat Tinggi" dan hasil uji ahli media dan desain dengan hasil perhitungan 1,00 menunjukkan kriteria "Sangat Tinggi".

Tabel 8. Rata-rata Pengujian Validitas

\begin{tabular}{|l|c|}
\hline \multicolumn{1}{|c|}{ Pengujian Ahli } & Hasil Perhitungan \\
\hline Ahli Isi & 1,00 \\
\hline $\begin{array}{l}\text { Ahli Desain dan } \\
\text { Media }\end{array}$ & 1,00 \\
\hline Rata-rata & 1,00 \\
\hline
\end{tabular}

Rata-rata hasil perhitungan uji validitas mendapatkan hasil 1,00, jika dikonversikan ke tabel kriteria rata-rata uji ahli menunjukkan tingkat validitas "Sangat

Langkah selanjutnya yaitu melakukan uji coba perorangan, uji coba kelompok kecil, uji coba lapangan, uji respon guru, dan uji respon siswa. Subjek uji perorangan adalah 3 orang siswa kelas $X$ TKJ. Yang terdiri atas satu orang dengan prestasi belajar tinggi, satu orang dengan prestasi belajar sedang, dan satu orang dengan prestasi belajar rendah. Prestasi belajar siswa ini dilihat dari hasil laporan nilai kelas. Dari hasil angket uji coba yang diisi oleh masingmasing siswa, 2 orang memberikan tanggapan sangat baik $(66,67 \%), 1$ orang memberikan tanggapan baik $(33,33 \%)$, dan tidak ada siswa yang memberikan
Tinggi". Dengan hasil perhitungan ini maka dapat dikatakan e-modul jaringan dasar "Valid" dan layak digunakan dalam pembelajaran tanggapan cukup, kurang, maupun sangat kurang. Rata-rata penilaian siswa adalah $89,33 \%$. Jika dikategorikan ke dalam tabel konversi termasuk dalam kategori "Baik". Hal ini menunjukkan bahwa pengembangan e-modul pada mata pelajaran Jaringan Dasar menunjukkan keberhasilan yang dibuktikan dengan terbantunya siswa dalam memahami materi Jaringan Dasar dan mempermudah proses pembelajaran tidak langsung, salah satunya adalah kemudahan diskusi dengan guru ataupun teman dalam forum yang telah disediakan. Berikut adalah grafik hasil uji coba perorangan.

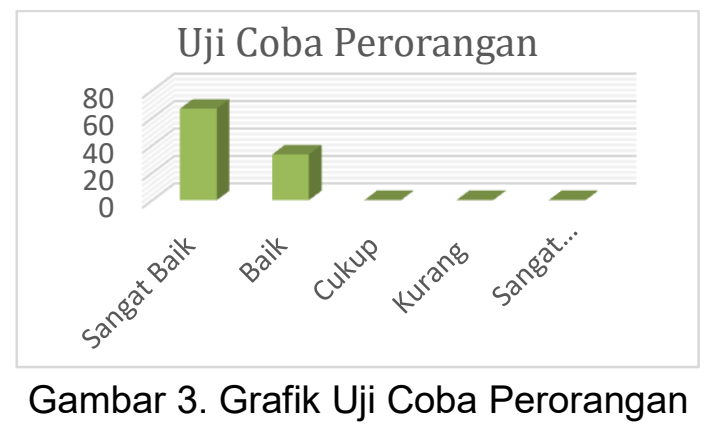

Uji kelompok kecil dilakukan oleh 12 orang siswa kelas $\mathrm{X}$ TKJ yang diklasifikasi menjadi 3 tingkatan yang terdiri atas 4 orang siswa dengan prestasi belajar tinggi 4 orang dengan prestasi belajar sedang, dan 4 orang dengan prestasi belajar rendah. 
Penentuan 12 orang siswa tersebut berdasarkan nilai yang didapatkan dari guru pengajar Jaringan Dasar. Dari hasil angket uji coba yang diisi oleh masing-masing siswa, terdapat 8 orang yang memberikan tanggapan sangat baik $(66,67 \%), 4$ orang memberikan tanggapan baik $(33,33 \%)$, dan tidak ada yang memberikan tanggapan cukup, kurang, maupun sangat kurang.
Rata-rata penilaian siswa adalah $89 \%$. Jika dikategorikan ke dalam tabel konversi termasuk dalam kategori "Baik". Hal ini menunjukkan keberhasilan terhadap produk e-modul Jaringan Dasar yang dibuktikan dengan persentase dalam kategori sangat baik dan baik serta terbantunya siswa dalam kemudahan belajar Jaringan Dasar

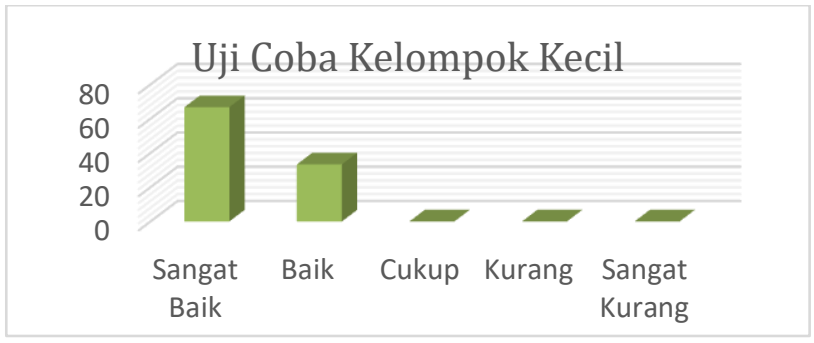

Gambar 4. Grafik Uji Coba Kelompok Kecil

Selanjutnya dilakukan uji coba lapangan, responden yang digunakan sebanyak 19 orang siswa kelas $X$ TKJ. Jumlah responden tersebut digolongkan berdasarkan tingkat prestasi dan pengetahuan yang berbeda-beda, mulai dari yang tinggi, sedang, hingga rendah. Dari hasil angket uji coba yang diisi oleh masing-masing siswa, terdapat 7 orang yang memberikan tanggapan sangat baik $(36,84 \%), 12$ orang memberikan tanggapan baik $(63,16 \%)$, dan tidak ada yang memberikan tanggapan cukup, kurang, maupun sangat kurang. Rata-rata penilaian siswa adalah $86,42 \%$. Jika dikategorikan ke dalam tabel konversi termasuk dalam kategori "Baik". Hal ini menunjukkan keberhasilan e-modul mata pelajaran Jaringan Dasar dengan baik, yang dibuktikan dengan terbantunya siswa dalam hal perolehan sumber belajar dan peningkatan perolehan pengalaman baru dalam proses pembelajaran dalam hal mempermudah proses belajar tidak langsung dan meningkatkan motivasi belajar.

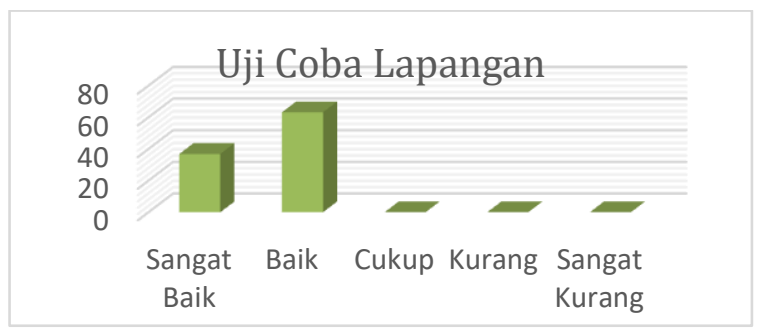

Gambar 5. Grafik Uji Coba Lapangan

Hasil uji coba perorangan, uji coba kelompok kecil, dan uji coba lapangan yang menunjukkan rentagan pengembangan emodul berada pada kategori "Sangat Baik" dan "Baik" ini mengindikasikan bahwa emodul membuat siswa lebih mudah belajar saat tidak ada proses pembelajaran secara langsung. 
Pemberian pretest dan post test diberikan saat uji lapangan agar mengetahui peningkatan hasil belajar siswa setelah menggunakan e-modul Jaringan Dasar. Hasil analisis pre test dan post test tersebut didapatkan rata-rata persentase kenaikan nilai sebesar $70,58 \%$ dari yang semula 5,1 adalah menjadi 8,7 . Selanjutnya adalah mencari nilai $N$-Gain atau Normalized Gain untuk mengetahui tingkat kenaikan hasil post test (Hake, 2002). Perhitungan yang diperoleh dari nilai $N$ Gain adalah 0.73 sehingga tingkat kenaikan hasil post test masuk ke kriteria "Tinggi" merujuk pada tabel kriteria normalized gain oleh (Hake, 2002). Berdasarkan hasil tersebut maka e-modul Jaringan Dasar sudah mampu meningkatkan hasil belajar siswa.

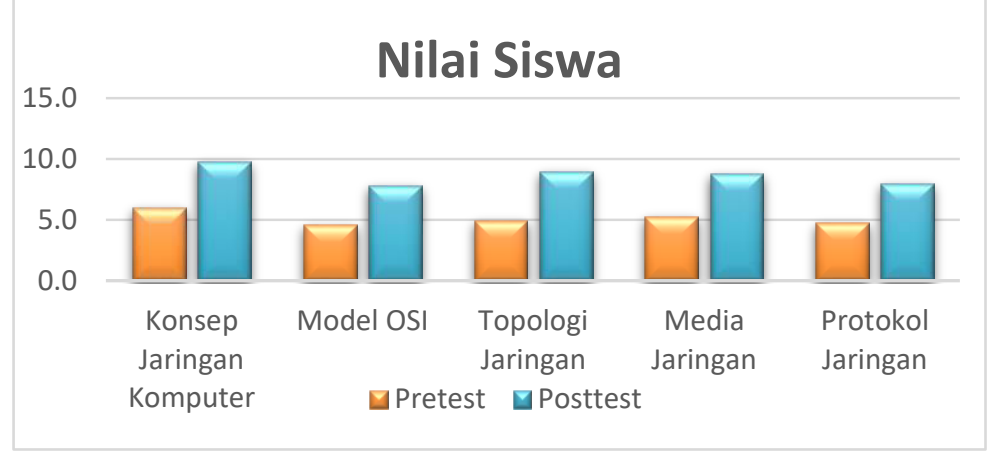

Selanjutnya dilakukan pengambilan respon guru terhadap pengembangan emodul Jaringan Dasar. Uji respon ini dilakukan oleh satu orang guru yang mengampu mata pelajaran jaringan dasar di kelas $X$ TKJ dan memperoleh rata-rata sebesar 46, jika dikategorikan ke dalam tabel kriteria penggolongan respon maka hasilnya termasuk ke dalam kategori sangat positif. Proses uji selanjutnya dilakukan dengan pengambilan respon siswa. Subjek uji coba respon adalah terdiri dari 19 orang siswa kelas $X$ TKJ yang telah belajar menggunakan e-modul. Hasil angket respon siswa terhadap pengembangan emodul Jaringan Dasar adalah sebesar $64,21 \%$, jika dikonversikan ke dalam tabel kriteria penggolongan respon maka hasilnya termasuk dalam kategori "Sangat Positif". Berdasarkan hasil respon guru dan siswa, maka e-modul dapat dikategorikan membantu siswa dalam memahami mata pelajaran Jaringan Dasar dan berhasil mengatasi permasalahan yang ada dalam proses belajar mengajar yang sudah dijelaskan sebelumnya. Dari perolehan respon tersebut mengindikasikan bahwa media pembelajaran dapat meningkatkan motivasi siswa untuk belajar sehingga mendapat hasil belajar yang optimal.

Hasil penelitian pengembangan emodul pada mata pelajaran jaringan dasar ini sejalan dengan (Wijayanti, 2016) yang membuat penelitian pengembangan e-modul berbasis project based learning pada mata pelajaran simulasi digital untuk siswa kelas $X$ studi kasus di SMK Negeri 2 Singaraja. Menggunakan model ADDIE dan menerapkan model pembelajaran project based learning. Hasil penilaian ahli isi berdasarkan angket sudah dinyatakan sesuai, hal tersebut mengindikasikan bahwa materi yang diimplementasikan pada e-modul sudah relevan. Persentase hasil uji coba perorangan adalah sebesar $88,3 \%$ berada pada kualifikasi baik. Persentase hasil uji coba kelompok kecil adalah $90,2 \%$ berada pada kualifikasi baik. Pada uji coba lapangan persentase yang dicapai adalah 90,6\% dan berada pada kualifikasi sangat baik. Hasil penelitian ini juga terkait dengan penelitian (Putri, 2014) yaitu pengembangan e-learning berbasis 
schoology pada mata pelajaran IPA kelas VIII di SMP Negeri 1 Seririt. Dimana latar belakang dari penelitian ini adalah kurangnya pemanfaatan fasilitas hotspot di sekolah dan rendahnya kualitas belajar IPA pada siswa dari kriteria ketuntasan minimal (KKM). Berdasarkan hasil evaluasi ahli isi, media e-learning berbasis schoology memperoleh tingkat pencapaian 90\% pada kualifikasi baik sehingga elearning schoology tidak perlu direvisi. Uji coba produk kepada ahli media mendapatkan persentase tingkat pencapaian sebesar $94 \%$ dan berada pada kualifiaksi baik. Hasil evaluasi dari ahli desaon memperoleh persentase tingkat pencapaian $94 \%$ dan jika dikonversi berada pada kualifikasi sangat baik. Berdasarkan hasil pembahasan, dapat diambil kesimpulan yaitu: dengan menggunakan model ADDIE dihasilkan media pembelajaran e-learning berbasis schoology pada mata pelajaran IPA kelas VIII di SMP Negeri 1 Seririt, kualitas e-learning berbasis schoology pada mata pelajaran IPA berdasarkan hasil evaluasi para ahli dan uji coba produk pada siswa menunjukkan kualifikasi baik.

E-modul Jaringan Dasar yang diterapkan di SMK TI Bali Global Singaraja dengan subjek uji coba yaitu siswa kelas $X$ TKJ dan guru pengajar Jaringan Dasar memiliki beberapa kelebihan dan kendala yang ditemukan selama penerapannya di sekolah. Adapun kelebihan dari e-modul Jaringan Dasar dengan menggunakan platform schoology antara lain: i) Emodul Jaringan Dasar memudahkan siswa dalam belajar mandiri sesuai dengan tuntutan Kurikulum 2013, ii) Emodul Jaringan Dasar meningkatkan kemandirian siswa dalam mencapai nilai kriteria ketuntasan melalui tahapantahapan model pembelajaran project based learning, iii) E-modul menambah semangat siswa dalam belajar Jaringan Dasar, karena pembelajaran dengan menggunakan e-modul membawa siswa pada pengalaman belajar baru yang belum pernah siswa dapatkan sebelumnya di sekolah, sehingga siswa memiliki rasa ingin tahu yang tinggi dalam belajar dengan menggunakan emodul, iv) E-modul Jaringan Dasar juga mudah diakses dimana saja dan kapan saja menggunakan perangkat smartphone. Sedangkan kedala yang ditemukan selama penerapannya adalah siswa belum menguasai penggunaan e-modul dengan menggunakan platform schoology, sehingga ketika dilakukan uji coba siswa masih memerlukan waktu untuk beradaptasi dengan penggunaan $e$ modul dalam pembelajaran. Solusi yang dapat digunakan dalam kegiatan ini adalah dengan mengarahkan siswa untuk membaca buku panduan pengguna yang sudah terdapat pada $e$ modul dan mendemokan cara penggunaannya. Kendala yang dihadapi peneliti yaitu pertama pada pengembangan e-modul Jaringan Dasar menggunakan Platform Schoology yaitu pada pengaturan jenis font yang akan digunakan pada saat pengimputan materi, yang keuda yaitu siswa belum menguasai penggunaan e-modul sehingga ketika dilakukan uji coba peneliti mengarahkan dan mendampingi siswa saat proses uji coba.

\section{KESIMPULAN}

Berdasarkan hasil penelitian dan pembahasan pada penelitian Pengembangan E-Modul Berbasis Model Pembelajaran Project Based Learning pada Mata Pelajaran Jaringan Dasar Kelas $X$ TKJ di SMK TI Bali Global Singaraja, maka penulis dapat menarik kesimpulan sebagai berikut. 
1. Hasil rancangan dan implementasi Pengembangan E-Modul Berbasis Model Pembelajaran Project Based Learning pada Mata Pelajaran Jaringan Dasar Kelas X TKJ di SMK TI Bali Global Singaraja menggunakan tahapan model project based learning sudah dinyatakan berhasil diterapkan. Hal ini dapat dilihat dari rata-rata persentase validasi e-modul berdasarkan hasil pengujian yang telah dilakukan sebesar 1,00. Jika dikonversikan ke dalam tabel konversi menunjukkan "Sangat Valid".

2. Respon guru terhadap Pengembangan E-Modul Berbasis Model Pembelajaran Project Based Learning pada Mata Pelajaran Jaringan Dasar Kelas X TKJ di SMK TI Bali Global Singaraja didapatkan rata-rata sebesar 46 . Jika dikonversikan ke dalam tabel kriteria penggolongan respon maka hasilnya termasuk dalam kategori positif. Sedangkan untuk respon siswa terhadap pengembangan emodul memperoleh rata-rata sebesar 64,21. Jika dikonversikan ke dalam tabel kriteria penggolongan respon maka hasilnya termasuk dalam kategori sangat positif.

\section{SARAN}

Berdasarkan pengamatan penulis, terdapat beberapa hal yang dapat dijadikan bahan pertimbangan untuk ditindak lanjuti.

1. Bagi pengembang e-modul selanjutnya agar dapat mengatur emodul lebih user friendly atau mudah digunakan oleh pengguna yang masih belum terbiasa dengan pembelajaran berbasis komputer. Selain itu, dapat mengatur agar setiap tahapan pembelajaran Project Based Learning ada fitur yang bisa memberikan tantangan baik berupa games atau bentuk lainnya dan pengembangan untuk pengaturan font pada Schoology bisa dilakukan seperti menggunakan office.

2. Produk e-modul berbasis model pembelajaran project based learning pada mata pelajaran jaringan dasar untuk siswa kelas $X$ TKJ di SMK TI Bali Global Singaraja yang dikembangkan belum sampai pada tahap pengukuran hasil belajar siswa Oleh karena itu, perlu diadakan pengkajian lebih lanjut mengenai efektivitas penggunaan $e-$ modul berkaitan dengan pengukuran hasil belajar dengan menggunakan e-modul ini melalui penelitian eksperimen dengan mengunakan konten dan model pembelajaran yang berbeda.

\section{REFERENSI}

Agustini, K. (2013). Pengaruh Penggunaan Simulasi Binary Tree Berbasis CAI Terhadap Motivasi dan Hasil Belajar Matematika Diskrit di Jurusan PTI UNDIKSHA. Jurnal Pendidikan Indonesia.

Anglada, D. (2007, Juli 10). An Introduction to Instructional Design. Retrieved from Utilizing a Basic Model: http://pace.edu/ctlt/newsletter

Aunurrahman. (2009). Belajar Pembelajaran. Bandung: Alfabeta.

Candiasa, I. M. (2010). Pengujian Instrumen Penelitian Desertasi ITEMAN dan BIGSTEP. Singaraja: UNDIKSHA.

Febrianita, N. K. (2016). Pengembangan EModul pada Mata Pelajaran Basis Data Kelas XII Berbasis Model 
Project Based Learning di SMK Negeri 2 Tabanan. Jurnal

Pendidikan Teknik dan Kejuruan.

Gregory, R. J. (2000). Phsycological Testing. United State of America: Allyn \& Bacon Inc.

Gunadharma, A. (2011). Pengembangan Emodul Sebagai Sumber Belajar Untuk Mata Kuliah Multimedia Design.

Hake, R. R. (2002). Analyze Change/Gain Score American Educational Research MEthodology. Retrieved from http://list.asu.edu/cgibin/wa?A2=ind9903\&1=aerad\&P=RG855

Ihksanudin, E. (2017, Juli 2). Model Pembelajaran Project Based Learning. Retrieved from http://ekaikhsanudin.net

Nurkancana, \& Sunartana. (1992). Evaluasi Hasil Belajar. Surabaya: Usaha Nasional.
Paramita, N. P. (2017). PENGEMBANGAN E-MODUL PEMBELAJARAN ADMINISTRASI SERVER. Jurnal Nasional Pendidikan Teknik Informatika.

Putri, N. W. (2014). Pengembangan ELearning Berbasis Schoology pada Mata Pelajaran IPA Kelas VIII di SMP Negeri 1 Seririt. Journal Edutech Universitas Pendidikan Ganesha (E-Journal).

Santyasa, I. W. (2011). Pembelajran Inovatif. Singaraja: UNDIKSHA.

Tegeh, I. M., \& Kirna, I. M. (2010). Metode Penelitian Pengembangan Pendidikan. Singaraja: Undiksha.

Wijayanti, N. P. (2016). pengembangan emodul berbasis project based learning pada matapelajaran simulasi digital untuk siswa kelas $X$ di SMK Negeri 2 Singaraja. jurnal pendidikan teknologi dan kejuruan. 